УДК 631.8:632.111.5: 633.854.79

(C) 2018

Гарбар Л. А., кандидат сільськогосподарських наук,

Яцишина Т. П., магістр,

Самолюк О. П., магістр

Національний університет біоресурсів і природокористування України

\title{
ВПЛИВ УДОБРЕННЯ НА ПЕРЕЗИМІВЛЮ РІПАКУ ОЗИМОГО
}

\section{Рецензент - кандидат сільськогосподарських наук Н. О. Ящук}

Наведено результати досліджень щзодо впливу на ріст, розвиток та перезимівлю рослин підживлень посівів ріпаку озимого комплексами мікродобрив «Реаком хелат бору» та "Квантум» у фазу чотирьохшести справжніх листків на фоні основного удобрення. Дослідження проводились протягом 20152017 рр. в умовах Лісостепу України на чорноземах типових малогумусних. У результаті проведених досліджень встановлено, що застосування позакореневих підживлень на фоні основного удобрення забезпечує задовільний ріст та розвиток рослин ріпаку озимого в період осінньої вегетаиії та дозволяс отримати високі показники збереженості рослин в період відновлення весняної вегетації. Вищчі показники збереженості рослин культури було отримано на варіантах із застосуванням $N_{80} P_{60} K_{80}+$ «Квантум» у фазу чотирьох-шести справжніх листків.

Ключові слова: ріпак озимий, удобрення, гібриди, позакореневі підживлення, осіння вегетаиія, збереженість рослин.

Постановка проблеми. Озимі культури за своєю біологією є найбільш пристосованими до використання осінньо-зимової вологи і тому забезпечують високі врожаї. Біологічна основа врожаю ріпаку озимого закладається восени i залежить насамперед від підготовки грунту до посіву, забезпечення поживними речовинами, від строків та способів сівби, норми висіву та погодних умов. У спеціальній та довідковій літературі наведено досить суперечливі дані про систему удобрення, строки та способи сівби та інші елементи технології вирощування. У виробництві це веде до недобору урожаю, а в кінцевому результаті - зниження значення ріпаківництва як галузі взагалі $[1,7]$. Саме тому перед науковцями постає завдання розробити рекомендації щодо науково обгрунтованої технології вирощування озимого ріпаку, яка забезпечить i розвиток оптимальних параметрів рослин восени, і їх успішну перезимівлю.

Озимий ріпак вважається надзвичайно чутливою до низьких температур культурою. За відсутності снігового покриву у поєднанні з тривалою мінусовою температурою спостерігається часткове пошкодження посівів або навіть повна загибель рослин. Обираючи для сівби ріпак озимий, варто пам'ятати, що морозостійкість різних гібридів ріпаку різна.

Перезимівля озимого ріпаку також залежить від технологічних умов вирощування в осінній період. Надзвичайно важливим етапом в розвитку ріпаку озимого $\epsilon$ період переходу від зими до весни, коли ми можемо візуально оцінити стан перезимівлі рослин і ступінь завданої шкоди посівам. Іноді втрати посівів озимого ріпаку сягають $100 \%$. Вони можуть бути зумовленими як чинниками, незалежними від господаря, так i помилками щодо вибору гібрида, засобів захисту, неправильного удобрення [3].

Аналіз основних досліджень і публікацій, у яких започатковано розв'язання проблеми. Озимий ріпак - дуже вимоглива до умов вирощування культура, особливо до умов перезимівлі. Кліматичні й грунтові умови мають значний вплив на розвиток рослин та їх продуктивність $[2,4]$.

Однією $з$ основних проблем, що призводить до втрат урожаю при вирощуванні ріпаку озимого, є перезимівля рослин. Попередні результати досліджень засвідчують, що вимерзають та гинуть загущені посіви та рослини пізніх строків сівби. Важливим чинником $є$ також морфологічні особливості рослин, які визначаються строками сівби, адже для формування оптимальних параметрів рослин перед зимівлею має минути певна кількість часу з відповідним температурним режимом та вологою.

Головним органом ріпаку озимого $є$ коренева шийка, діаметр якої перед входом у зиму має становити 8-10 мм. Важливим аспектом є також розмір і кількість листків, які в зимовий період прикриватимуть кореневу шийку від вимерзання, що теж забезпечується оптимальним строком сівби. Враховуючи сучасні зміни клімату, особливо в останні роки, важливо забезпечити рослини доступною вологою в період формування сходів.

Ріпак озимий потребує великої кількості по- 
живних речовин. Літературні джерела містять суперечливі дані щодо норм добрив, які необхідно використовувати для удобрення цієї культури $[5,6,8]$. Тому в оптимізації мінерального живлення криється величезний невикористаний резерв підвищення продуктивності ріпаку та ефективності господарювання.

Дефіцит елементів живлення призводить до уповільнення росту, недостатнього накопичення необхідних для перезимівлі пластичних речовин (вуглеводів). Невиконання будь-якого елементу технології призводить до погіршення зимостійкості рослин і збільшує ризик їх вимерзання взимку.

Успіх перезимівлі залежить не тільки від сприятливих погодних умов, але й від стану посівів у осінній період, тобто розвитку рослин. Важливим $є$ формування в осінній період потужних, проте не перерослих рослин.

Метою наших досліджень було вивчення впливу різних варіантів удобрення гібридів ріпаку озимого на формування продуктивності культури в умовах Лісостепу України на чорноземах типових малогумусних.

Матеріали і методи досліджень. Предметом досліджень були посіви ріпаку озимого гібридів Ексель та Дембо. Дослідження проводили відповідно до загальноприйнятих методик протягом 2015-2017 рр. Польові досліди закладали за методом розщеплених ділянок. Попередник - пшениця озима. Площа облікової ділянки - $25 \mathrm{~m}^{2}$. Повторення - чотириразове. Схема досліду передбачала вивчення наступних факторів:

Фактор А - Гібриди: Ексель і Дембо.
Фактор Б - удобрення: 1. $\mathrm{N}_{80} \mathrm{P}_{60} \mathrm{~K}_{80}$ (контроль); 2. $\mathrm{N}_{80} \mathrm{P}_{60} \mathrm{~K}_{80}+$ «Квантум» (4-6 справжніх листків); 3. $\mathrm{N}_{80} \mathrm{P}_{60} \mathrm{~K}_{80}+$ «Реаком хелат бору» (4-6 справжніх листків).

Результати досліджень. Результати досліджень показали, що застосування у підживлення комплексу мікроелементів на фоні основного удобрення мало позитивний ефект на ріст та розвиток рослин ріпаку озимого у період осінньої вегетації.

Рослини ріпаку озимого гібриду Дембо досягнули висоти 21,5-25,5 cм залежно від варіантів досліду. Довжина кореневої системи сягала 10,1-13,4 см. На рослині на даний період сформувалося по 6,2-7,4 листків із довжиною листкової пластинки 9,2-10,2 cм. Діаметр кореневої шийки становив 8,1-10,3 мм (рис. 1).

Після внесення «Квантуму» та «Реаком хелат бору» прослідковується підвищення всіх показників у варіантах із використанням препарату «Квантум». Розвиток рослин ріпаку озимого гібриду Дембо на час припинення осінньої вегетації (залежно від позакореневого підживлення рослин) знаходився в межах оптимальних параметрів для рослин, що входять у зиму.

Аналогічні результати прослідковувались i щодо показників рослин ріпаку озимого гібриду Ексель. Вони досягнули висоти 22,8-25,9 см залежно від варіантів досліду. Довжина кореневої системи сягала 13,4-15,6 см. На рослині сформувалося по 7,3-7,9 листків із довжиною листкової пластинки $10,5-1,07$ см. Діаметр кореневої шийки становив 9-11,1 мм (рис. 2).

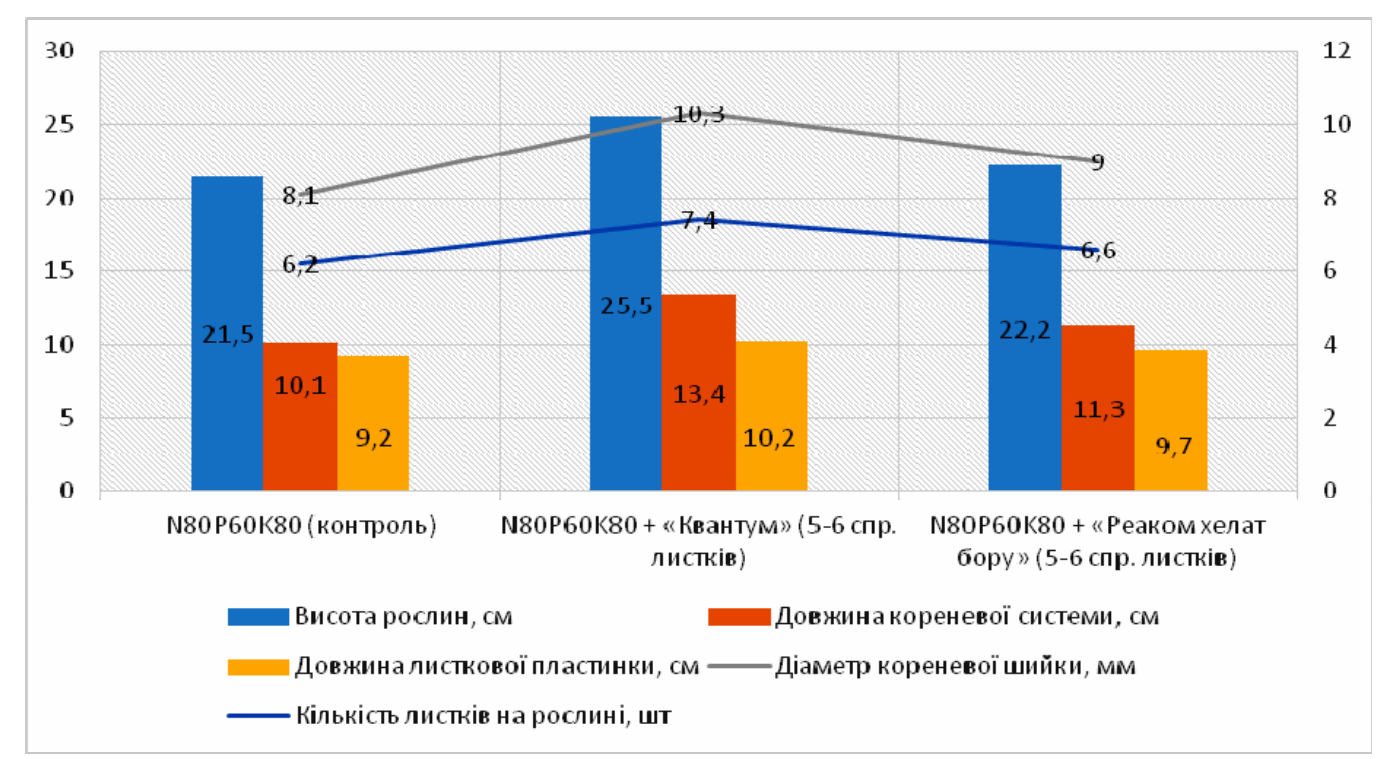

Рис. 1. Розвиток рослин ріпаку озимого гібриду Дембо на час припинення осінньої вегетації залежно від позакореневого підживлення рослин (середнє за 2015-2017 рр.). 


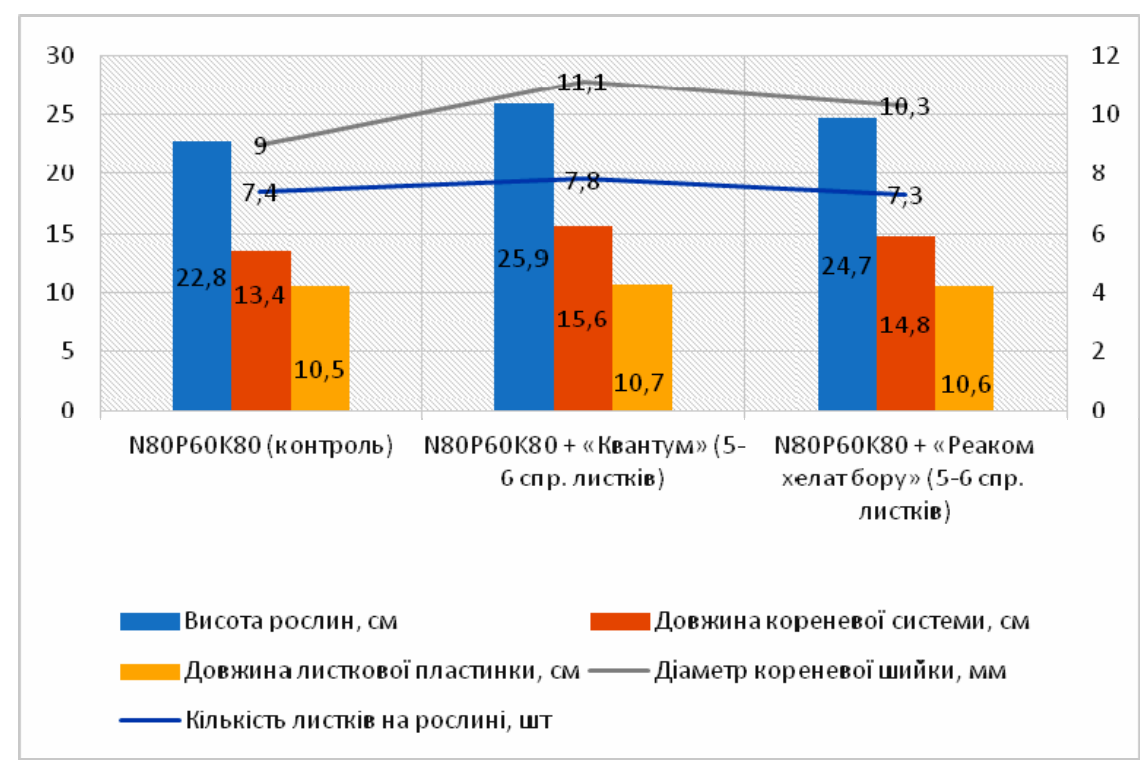

Рис. 2. Розвиток рослин ріпаку озимого гібриду Ексель на час припинення осінньої вегетації залежно від позакореневого підживлення рослин (середнє за 2015-2017 рр.)

1. Збереження рослин гібридів ріпаку озимого залежно від підживлення мікроелементами, \%

\begin{tabular}{|c|l|c|c|c|}
\hline \multirow{2}{*}{ Гібрид } & \multicolumn{1}{|c|}{ Варіант внесення добрив } & 2016 & 2017 & $\begin{array}{c}\text { Середнє } \\
2016-2017\end{array}$ \\
\hline \multirow{3}{*}{ Ексель } & $\mathrm{N}_{80} \mathrm{P}_{60} \mathrm{~K}_{80}$ (контроль) & 65,7 & 64,7 & 65,2 \\
\cline { 2 - 5 } & $\mathrm{N}_{80} \mathrm{P}_{60} \mathrm{~K}_{80}+$ «Квантум» & 75,3 & 70,8 & 73,05 \\
\cline { 2 - 5 } & $\mathrm{N}_{80} \mathrm{P}_{60} \mathrm{~K}_{80}+$ «еаком хелат бору» & 72,1 & 68,8 & 70,45 \\
\hline \multirow{3}{*}{ Дембо } & $\mathrm{N}_{80} \mathrm{P}_{60} \mathrm{~K}_{80}$ (контроль) & 62,5 & 64,3 & 63,4 \\
\cline { 2 - 5 } & $\mathrm{N}_{80} \mathrm{P}_{60} \mathrm{~K}_{80}+$ «Квантум» & 70,2 & 67,4 & 68,8 \\
\cline { 2 - 5 } & $\mathrm{N}_{80} \mathrm{P}_{60} \mathrm{~K}_{80}+$ «Реаком хелат бору» & 67,1 & 66,2 & 66,65 \\
\hline
\end{tabular}

Загалом, порівнюючи отримані результати, можна зробити висновок, що внесення комплексу мікроелементів «Квантум» забезпечувало краще формування рослин у осінній період. Аналізуючи відсоток збережених рослин досліджуваних гібридів (таблиця 1), можна зробити висновок, що вищою зимостійкістю характеризується гібрид Ексель. Відсоток збережених рослин на необроблених варіантах у даних гібридів $\epsilon$ найнижчими.

Підживлення гібридів Дембо та Ексель комплексом мікродобрив позитивно вплинуло на їх перезимівлю. У середньому відсоток збережених рослин на 3-8\% більший у варіантах, на яких проводилось внесення мікродобрив, ніж на необроблених ділянках контролю. Причому відсоток збережених рослин $є$ вищим у варіантах

\section{БІБЛІОГРАФІЯ}

1. Інтенсивна технологія вирощування озимого ріпаку в Україні / [Лазар T.I., Лапа О.М., Чехов А.В., Свидинюк I.М. та ін.]. $-2006,-102$ с. iз застосуванням комплексу «Квантум», ніж при підживленні «Реаком хелат бору».

Варто відмітити, що найвищий відсоток перезимівлі під час проведення досліджень у середньому за два роки було відмічено у гібриду Ексель 3 показником 73,05 \%.

Висновки. Аналізуючи результати досліджень, можна зробити висновки, що застосування позакореневих підживлень на фоні основного удобрення забезпечує задовільний ріст та розвиток рослин ріпаку озимого в період осінньої вегетації та дозволяє отримати високі показники збереженості рослин в період відновлення весняної вегетації. Вищі показники збереженості рослин культури було отримано на варіантах із застосуванням $\mathrm{N}_{80} \mathrm{P}_{60} \mathrm{~K}_{80}+$ «Квантум» у фазу чотирьох-шести справжніх листків.

2. Камінська T. В. Вміст олії у насінні ріпака ярого залежно від технології вирощування / Т. В. Камінська // Вісник ЖНАЕУ. - 2009. - № 1. - C. 262-268. 
3. Ковальчук Д. Оцінка перезимівлі озимого ріпаку / Д. Ковальчук // Спецвипуск ж. Пропозиція. Озимий ріпак технології прибутковості / - 2016. C. 32-34.

4. Лагущ Н. Продуктивність озимого ріпаку на дерново-підзолистих грунтах. Передкарпаття залежно від удобрення / Н. Лагуш, С. Гуринович, О. Гуринович // Вісник. Львівського національного аграрного університету : агрономія. - 2009. - № 13. - С. 13-17, 21.

5. Марков I. Хвороби ріпак / I. Марков // Агробізнес сьогодні. - 2010. - №15/16. - С. 18-25.
6. Марчук I. Добрива - основа отримання стабільних врожаїв / I. Марчук II Агроном. 2003. - № 11. - C. 11-13.

7. Мельник I. I. Комплексна механізація виробництва озимого ріпаку / I. I. Мельник, В. Д. Гречкосій , В. В. Марченко // Пропозиція. 2004. - № 2. - С. 46-50.

8. Санін Ю. В. Осінне підживлення озимих культур: важливий агротехнічний захід підвищення стійкості культур до перезимівлі та дружного старту навесні! / Ю. В. Санін // Агроном. 2010. - №3. - C. 26-27. 